\title{
Effects of Daily Temperature Highs on Development of Phakopsora pachyrhizi on Soybean
}

\author{
M. R. Bonde, S. E. Nester, and D. K. Berner
}

United States Department of Agriculture-Agricultural Research Service, 1301 Ditto Ave., Fort Detrick, MD 21702. Accepted for publication 26 April 2012.

\begin{abstract}
Bonde, M. R., Nester, S. E., and Berner, D. K. 2012. Effects of daily temperature highs on development of Phakopsora pachyrhizi on soybean. Phytopathology 102:761-768.

Although considerable information exists regarding the importance of moisture in the development of soybean rust, little is known about the influence of temperature. The purpose of our study was to determine whether temperature might be a significant limiting factor in the development of soybean rust in the southeastern United States. Soybean plants infected with Phakopsora pachyrhizi were incubated in temperature-controlled growth chambers simulating day and night diurnal temperature patterns representative of the southeastern United States during the growing season. At 3-day intervals beginning 12 days after inoculation, urediniospores were collected from each plant and counted. The highest numbers of urediniospores were produced when day temperatures peaked at 21 or $25^{\circ} \mathrm{C}$ and night temperatures dipped to 8 or $12^{\circ} \mathrm{C}$. When day temperatures peaked at 29,33 , or $37^{\circ} \mathrm{C}$ for a minimum of $1 \mathrm{~h} /$ day,
\end{abstract}

ABSTRACT urediniospore production was reduced to 36,19 , and $0 \%$, respectively, compared with urediniospore production at the optimum diurnal temperature conditions. Essentially, no lesions developed when the daily temperature high was $37^{\circ} \mathrm{C}$ or above. Temperature data obtained from the National Climatic Data Center showed that temperature highs during July and August in several southeastern states were too high for significant urediniospore production on 55 to $77 \%$ of days. The inhibition of temperature highs on soybean rust development in southeastern states not only limits disease locally but also has implications pertaining to spread of soybean rust into and development of disease in the major soybeanproducing regions of the Midwestern and northern states. We concluded from our results that temperature highs common to southeastern states are a factor in the delay or absence of soybean rust in much of the United States.

Additional keywords: temperature peak.
Soybean rust, caused by Phakopsora pachyrhizi Syd. \& P. Syd., was discovered in Japan in 1902 (10) and, since then, has been reported from Africa (14), Australia (5), and South America $(18,22)$. In November 2004 , discovery of soybean rust in the southeastern United States generated considerable concern because of the possible threat to U.S. agriculture (23). In many parts of the world, soybean rust has caused significant yield loss, becoming a major constraint to soybean production (5).

$P$. pachyrhizi, an obligate pathogen, is capable of overwintering on the leguminous weed kudzu in isolated areas of the southeastern United States (4). Temperature and moisture are the two most important environmental factors affecting soybean rust development (5). Moisture is widely recognized as an important determinant of soybean rust development and often is described as the driving force $(5,19)$. Moisture in the form of dew is generally present on $50 \%$ or more evening to early-morning periods during much of the growing season in most U.S. soybeanproducing areas $(13,16,17,21)$. In addition, rain can provide the necessary moisture for disease development but usually occurs less frequently and can be absent for extended periods of time. Eversmeyer et al. (8) reported that dew is the major source of free

Corresponding author: M. R. Bonde

E-mail address: morris.bonde@ars.usda.gov

Mention of trade names or commercial products in this publication is solely for the purpose of providing specific information and does not imply recommendation or endorsement by the United States Department of Agriculture.

http://dx.doi.org/10.1094/PHYTO-01-12-0011-R

This article is in the public domain and not copyrightable. It may be freely reprinted with customary crediting of the source. The American Phytopathological Society, 2012 water promoting wheat leaf rust in the Great Plains, and the most accurate predictor of moisture available for rust development. Consequently, there is reason to believe that the same holds true for soybean rust because the environmental requirements are similar (16). Melching et al. (16) concluded that, throughout most soybean-producing areas of the United States, late spring and early summer dew periods would readily permit soybean rust initiation and maintenance if inoculum was present.

However, in spite of survival of the pathogen through the winter in southeastern states and the apparent favorable moisture requirements necessary for development of soybean rust, in general, the disease has remained at low levels in the United States. When disease did become severe, it was not until the fall, too late to significantly affect crop yield. The lack or delay of soybean rust could be the result of any of several factors. For example, Li et al. (15) suggested that the delay of soybean rust in North America was associated with exposure of urediniospores to sunlight, which is detrimental to their viability, germination, and infection efficiency. Disease was suppressed during June and July, when day lengths were near maximum, but, as days became shorter during the fall, disease increased. They believed that the delayed appearance of soybean rust could not be explained by daytime temperatures or opportunities for urediniospore dispersal (15).

However, a survey of the literature by Bromfield (5) showed that in Asia, where multiple-season cropping is practiced, soybean rust was much more severe during the cool seasons accompanied by rain. The relationship of daytime temperature to soybean rust development has not been resolved.

The purpose of our study was to more precisely define the effects of daytime temperature and, in particular, effects of daytime temperature highs, generally lasting 1 to a few hours, on 
development of soybean rust. Our hypothesis was that $P$. pachyrhizi is highly sensitive to peak day temperatures commonly reached during summer months in the southeastern United States, and this susceptibility to heat is at least partly responsible for the lack or delay of rust until cooler weather. Because the pathogen does not survive through the winter in Midwestern and northern states, major soybean-producing regions of the United States, the presence of soybean rust in southeastern United States is particularly important. Urediniospores of $P$. pachyrhizi and soybean rust progressively move in a south to north direction during growing seasons. Without disease in the southeast, soybean rust will not occur in the Midwest and north. An understanding of the relationship of soybean rust development to temperature highs would add to the accuracy and usefulness of soybean rust disease prediction models for the United States

\section{MATERIALS AND METHODS}

Diurnal temperature patterns characteristic of the southeastern U.S. states. In order to determine characteristic temperature patterns during the growing season in the southeastern United States with which to set growth chambers, the average daily maximum and minimum temperatures for each month over a 24to 56-year period (duration dependent on number of years data collected) were obtained from the Southeast Regional Climate Center website (www.sercc.com) for five weather stations, one in each of five southeastern states (Table 1). Each weather station was selected primarily based on proximity to an area where rust had been reported in 2007. The weather stations were located in Tallahassee, FL; Montgomery, AL; Butler, GA; Columbia, SC; and Kinston, NC. For each weather station, average differences between mean maximum and minimum temperatures for each month of the year for each location were calculated (Table 1). Taken together, the data provided a broad picture of temperature conditions across the southeastern United States.

To determine average durations of temperature highs and lows and time of day they occurred, continuous temperature data for a 4-year period, 2000 to 2003, from a field weather station in Griffin, GA, managed by the Foreign Disease-Weed Science Research Unit (FDWSRU), United States Department of Agriculture-Agricultural Research Service, was examined. Times of sunrise and sunset and durations of dawn and dusk were based on a calendar for Atlanta, GA at the website www.sunrisesunset.com/calendar.asp.

Pathogen and host. $P$. pachyrhizi isolate Alabama 04-1, from Mobile County, AL, collected in 2004, was used throughout the study. The isolate was purified by serial passage through several rounds of single pustules on the soybean 'Williams'. Studies conducted at FDWSRU indicated that this isolate was typical of all United States isolates in the FDWSRU soybean rust collection with respect to aggressiveness and response to environmental conditions (M. R. Bonde, S. E. Nester, and D. K. Berner, unpublished data; 1$)$.
Soybean plants (Williams) were grown in 10.2-cm-diameter clay pots for 30 days, then transferred to 20 -cm-diameter clay pots. Potting soil used throughout the study was the standard soil mix used at FDWSRU, containing a peat and compost-based mix $(60 \%)$, coarse perlite $(24 \%)$, coarse vermiculite $(8 \%)$, sand $(8 \%)$, 10-10-10 fertilizer, lime, trace minerals, and a wetting agent. After an additional 20 days, all leaves except four trifoliolate leaves (leaves 5 through 8 or 6 through 9) per plant were removed. Pruning allowed remaining leaves on the plants to be under essentially identical environmental conditions while in dew chambers and later, when infected plants were present in growth chambers. The plants were given $16 \mathrm{~h}$ of supplemental lighting per day in the greenhouse and fertilized with 14-14-14 Osmocote (Scotts Miracle-Gro Company, Marysville, $\mathrm{OH}$ ).

General experimental setup. Plants were inoculated by dipping the four trifoliolate leaves per plant individually into a urediniospore suspension $\left(3 \times 10^{4}\right.$ urediniospores $\left./ \mathrm{ml}\right)$ in aqueous $0.04 \%$ Tween 20 in a 2 -liter beaker. Inoculated plants were incubated overnight in a $20^{\circ} \mathrm{C}$ dew chamber and, the next day, distributed to three temperature-controlled growth chambers. For each experiment, each chamber was programmed to operate at a specific day-and-night diurnal temperature cycle determined by temperature data from weather stations, as previously described. Experiments were conducted in sets of three, with each set including one temperature pattern also included within a different set of experiments. The temperature patterns, designated by their diurnal temperature highs, were $17^{\circ} \mathrm{C}$ (three runs), $21^{\circ} \mathrm{C}$ (three runs), $25^{\circ} \mathrm{C}$ (six runs), $29^{\circ} \mathrm{C}$ (three runs), $33^{\circ} \mathrm{C}$ (six runs), $37^{\circ} \mathrm{C}$ (three runs), and $41^{\circ} \mathrm{C}$ (three runs). The temperature profiles with 25 and $33^{\circ} \mathrm{C}$ highs each had six runs instead of three because, as stated, these temperature conditions were used to overlap two sets of experiments. For each temperature pattern, the diurnal temperature low was $13^{\circ} \mathrm{C}$ below the diurnal high, the difference based on average temperature differences according to long-term records for the southeastern United States. Three plants were included for each temperature pattern in each run.

In each growth chamber, the temperature was gradually raised from a temperature low at 6:00 to 7:00 a.m. to a high at 4:00 to 5:00 p.m., with 1-h durations at the two temperature extremes. Day length was $14 \mathrm{~h}$ with fluorescent and incandescent lights. Twilight was 6:30 to 7:00 a.m. and dusk 9:00 to 9:30 p.m., each with only incandescent lights.

Plants in growth chambers were automatically watered twice per day from drip tubes, such that the soil in each pot reached saturation and subsequently partially dried. They were examined regularly to ensure that none of the plants became stressed from over or under watering. A Hobo H8 Pro Serieslogger (Onset Computer Corporation), with an accuracy of $\pm 3.0 \%$, based on information from the manufacturer, continuously monitored the relative humidity $(\mathrm{RH})$ in each chamber. A summary of the $\mathrm{RH}$ levels is presented in Table 2. Results from an ancillary study in which plants were maintained in growth chambers at 20 or $90 \%$ $\mathrm{RH}, 29^{\circ} \mathrm{C}$ (day), and $16^{\circ} \mathrm{C}$ (night) for the entire postinoculation

TABLE 1. Mean daily minimum and maximum temperature for each month of the cropping season over a 24- to 56-year period for five field locations, one in each of five southeastern states

\begin{tabular}{|c|c|c|c|c|c|c|c|c|}
\hline \multirow[b]{2}{*}{ State } & \multicolumn{8}{|c|}{ Month (minimum/maximum) } \\
\hline & April & May & June & July & August & September & October & November \\
\hline Florida & $11.7 / 26.7$ & $16.7 / 30.6$ & $20.6 / 32.2$ & $22.2 / 32.8$ & $22.2 / 32.8$ & $20.0 / 31.1$ & $13.9 / 27.2$ & $8.3 / 22.2$ \\
\hline Alabama & $12.8 / 24.4$ & $17.8 / 28.9$ & $21.7 / 32.2$ & $22.8 / 32.8$ & $22.2 / 32.8$ & $20.0 / 30.0$ & $13.9 / 25.6$ & $7.8 / 18.9$ \\
\hline South Carolina & $10.0 / 24.4$ & $15.0 / 28.9$ & $19.4 / 31.7$ & $21.7 / 33.3$ & $21.1 / 32.8$ & $17.8 / 29.4$ & $10.6 / 24.4$ & $5.0 / 19.4$ \\
\hline North Carolina & $8.9 / 23.9$ & $13.9 / 27.8$ & $18.3 / 30.6$ & $20.6 / 32.2$ & $20.0 / 31.7$ & $16.7 / 28.9$ & $10.6 / 24.4$ & $6.1 / 19.4$ \\
\hline Average & $10.3 / 24.8$ & $15.3 / 29.0$ & $19.4 / 31.6$ & $21.3 / 32.8$ & $21.0 / 32.6$ & $18.1 / 29.5$ & $11.7 / 25.1$ & $6.3 / 20.1$ \\
\hline
\end{tabular}

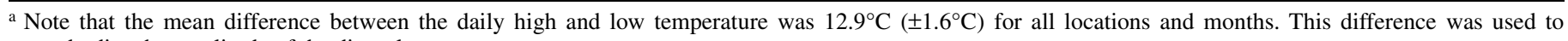
standardize the amplitude of the diurnal temperature patterns. 
period showed that $\mathrm{RH}$ had no significant effect on numbers of lesions, uredinia per lesion, or urediniospore production if plants never became stressed by over or under watering.

Relationship of leaf to air temperature. Of leaf and air temperature, the leaf temperature probably has the greater influence on the pathogen. In order to determine the relationship of leaf to air temperature, simultaneous leaf surface and air temperatures were collected and recorded by means of a watchdog Model 225 datalogger (Spectrum catalog number 3681; Spectrum Technologies, Inc., Plainfield, IL) with an external Temperature Sensor (Spectrum catalog number 3667s; Spectrum Technologies, Inc.). A datalogger within a radiation shield was mounted on a ring stand in each growth chamber. The temperature sensor was attached to a plant stake by means of a twist tie and the sensor tip held in contact with the leaf surface by slight pressure. Leaf surface and air temperatures were recorded with an accuracy of $\pm 0.6^{\circ} \mathrm{C}$. In each test, data were collected for a 3-day period. Two tests were conducted for the $25^{\circ} \mathrm{C}$ (high) and $12^{\circ} \mathrm{C}$ (low) profile, one for the 29 and $16^{\circ} \mathrm{C}$ profile, and two for the 33 and $20^{\circ} \mathrm{C}$ profile. The average difference between leaf surface and air temperature for each test was calculated for each temperature profile for the periods dawn, day, dusk, and night.

Numbers of lesions. At the end of each experiment, the four inoculated trifoliolate leaves of each plant were removed, placed on damp paper towels in metal pans, and incubated $\approx 16 \mathrm{~h}$ in a $4{ }^{\circ} \mathrm{C}$ cold room to enhance lesion visibility. The next day, each leaf (a total of 12 leaflets) from each of three sample plants per temperature pattern (equals one growth chamber) were photographed for later examination of digital images to enumerate numbers of lesions and leaf areas of inoculated leaves. For each leaf that dropped (thus, removed) from a plant, the date and position of the leaf were recorded and digital images used for further adjustment of lesion numbers over time. The procedure allowed a determination of number of lesions contributing to urediniospore counts for each plant at 3-day intervals.

Numbers of uredinia per lesion and uredinium diameters. At the end of each experiment, representative leaflets for each temperature profile were fixed in Farmer's solution, cleared of pigments in lactophenol, and stained in $0.1 \%$ cotton blue in lactophenol as previously described (2). Leaf pieces were examined microscopically at $\times 20$ magnification to determine the average number of uredinia per lesion based on 25 lesions, and examined at $\times 90$ magnification to determine average uredinium diameters, measured by means of a micrometer, of 25 uredinia for each temperature profile in each experiment. The average sporeproducing area per lesion (SPAL) for each temperature profile in each experiment was calculated by multiplying the average number of uredinia per lesion by the average uredinium crosssectional area.

Numbers of urediniospores. Beginning 12 days after inoculation in 3-day intervals, urediniospores were collected until 33 days after inoculation (eight collections) by vacuum harvester (6) from each plant by insertion of leaflets, loosely rolled, into the metal cylinder of the spore collector. Urediniospores, vacuumed from the leaves as they were collected, were deposited into two glass vials attached to the spore harvester. Each plant was considered a sample, and urediniospores were enumerated at 3day intervals by means of a hemocytometer. At the end of the experiment, total numbers of urediniospores produced by each plant and urediniospores produced per lesion during the course of the experiment were calculated.

Mean daily maximum and minimum temperatures for representative southeastern and Midwestern states. In order to test the hypothesis that "extreme" temperature highs might be responsible for the absence of soybean rust in various regions of the United States, it was necessary to determine the frequency at which a specific temperature was exceeded. Daily temperature maxima were obtained from the National Climate Data Center for seven states, including representative Midwestern states, for 2002, 2003, 2004, and 2005 (Table 3) and used to calculate the frequency in which $33^{\circ} \mathrm{C}$ was exceeded for each month, April to November, averaged over 4 years, for each location (Table 4).

Data analyses. In total, seven temperature patterns were tested in nine repetitions in time in three environmental growth chambers. Each repetition included three plants at three temperature patterns, one pattern in each of three growth chambers, and one of these patterns was included within another repetition. Thus, temperature patterns were tested in unequal numbers of incomplete repetitions. Five temperature patterns were tested three times each and two other temperature patterns six times each, as previously described. Within each repetition and growth chamber, each temperature profile had three sample plants.

The experimental design was a randomized incomplete block design with repetitions as random block effects and growth chambers and temperature patterns as fixed effects. The data were analyzed as mixed models using the SAS PROC MIXED procedure (version 9.2; SAS Institute, Cary, NC). Repetition was specified as a random effect and a repeated statement was used to indicate that correlated observations occurred within the random repetition-fixed growth chamber effect. An unstructured covariance structure was specified to completely define the variance-covariance structure. The experimental error term was repetition-growth chamber-temperature profile. Denominator degrees of freedom were determined using the Kenward-Roger correction (12). Least squares means for temperature profiles, standard errors of the least squares means, and probabilities of differences among these profiles were generated for each variable using an lsmeans statement. Bar graphs for each variable were constructed from the least squares means, standard errors, and probabilities of differences among the patterns.

Correlations between air and leaf temperatures were run for each light regime (i.e., incandescent only, incandescent plus fluorescent, and darkness) in growth chambers with 25 and $33^{\circ} \mathrm{C}$ highs.

\section{RESULTS}

Diurnal temperature patterns characteristic of the southeastern U.S. states. The amplitudes of the diurnal temperature patterns were remarkably similar regardless of location or month of year. Data for April to November are presented in Table 1. On average, there was a $12.8^{\circ} \mathrm{C}\left( \pm 1.6^{\circ} \mathrm{C}\right)$ difference between the high and low temperature averages for the five weather station locations, one in each of five states, for each of the eight months over a 24- to 56-year period (Table 1). Therefore, we considered that, on average, there was an $\approx 13^{\circ} \mathrm{C}$ difference between the mean daily high and low, regardless of month or location. Based on examination of continuous temperature data over a 3-year period

TABLE 2. Relationship of temperature highs and lows to relative humidity (RH) highs and lows during experiments in which temperature patterns simulated conditions in nature

\begin{tabular}{|c|c|c|c|}
\hline \multicolumn{2}{|c|}{ Temperature $\left({ }^{\circ} \mathrm{C}\right)^{\mathrm{a}}$} & \multicolumn{2}{|c|}{$\mathrm{RH}(\%)^{\mathrm{b}}$} \\
\hline High & Low & High & Low \\
\hline 41 & 28 & 24 & 92 \\
\hline 37 & 24 & 45 & 82 \\
\hline 33 & 20 & 45 & 96 \\
\hline 29 & 16 & 48 & 95 \\
\hline 25 & 12 & 63 & 92 \\
\hline 21 & 8 & 70 & 91 \\
\hline 17 & 4 & 76 & 92 \\
\hline
\end{tabular}

a Temperature highs occurred each day from 4:00 to 5:00 p.m. with all lights on and lows occurred each day from 6:00 to 7:00 a.m. without lights.

${ }^{\mathrm{b}} \mathrm{RH}$ high occurred when the temperature was at its lowest level and low occurred when the temperature was at its highest level. 
at the Griffin, GA field plot, we determined the average duration at temperature highs and lows each to be $\approx 1 \mathrm{~h}$. Twilight and sunset periods were each considered to be $\approx 0.5 \mathrm{~h}$. The day length of $14 \mathrm{~h}$ was selected as the standard day length for all growth chambers.

Seven temperature patterns were determined to be adequate to represent the range of temperature patterns representative of the southeastern states throughout the growing season. As expected, each pattern represented multiple locations and times of year. In general, a $17^{\circ} \mathrm{C}$ high and $4^{\circ} \mathrm{C}$ low represented the months of December and February; $21^{\circ} \mathrm{C}$ high and $8^{\circ} \mathrm{C}$ low represented March and November; $25^{\circ} \mathrm{C}$ high and $12^{\circ} \mathrm{C}$ low represented April and October; $29^{\circ} \mathrm{C}$ high and $16^{\circ} \mathrm{C}$ low represented May and September; and $33^{\circ} \mathrm{C}$ high and $20^{\circ} \mathrm{C}$ low represented June, July, and August. Temperatures-month for each location are summarized in Table 1.

Relationship of leaf to air temperature. During dawn and dusk, with only incandescent lights on, the average leaf temperature was $0.2^{\circ} \mathrm{C}$ below to $0.6^{\circ} \mathrm{C}$ above that of the corresponding ambient air temperature in the growth chamber. With incandescent and fluorescent lights on during the day, average measurements for leaf temperatures were 0.5 to $1.2^{\circ} \mathrm{C}$ above that of the air temperature and, at night (without lights), leaf temperatures were $0.2^{\circ} \mathrm{C}$ below to $0.04^{\circ} \mathrm{C}$ above that of the air. Accuracy of the temperature probes was $\pm 0.6^{\circ} \mathrm{C}$, an amount equal to or greater than many of the average differences measured between the leaf and air temperature. The results suggest that leaf and air temperatures in growth chambers were always nearly equal. Pearson's coefficients for correlations between air and leaf temperature for growth chambers at $25^{\circ} \mathrm{C}$ high were 0.99 for all three light regimes. For growth chambers at $33^{\circ} \mathrm{C}$ high, the correlation coefficients were $0.99,0.97$, and 0.96 for incandescent only, incandescent plus fluorescent, and darkness, respectively. All coefficients were significant at $P<0.0001$.

Numbers of lesions. The greatest number of lesions (6.2 lesions $/ \mathrm{cm}^{2}$ of leaf area) were produced when the growth chamber temperature peaked at $21^{\circ} \mathrm{C}$; however, there were no significant differences among any of the temperature patterns for which

TABLE 3. Highest temperature $\left({ }^{\circ} \mathrm{C}\right)$ and mean daily temperature high, for each month (April to November) at each of seven weather stations ${ }^{\mathrm{a}}$

\begin{tabular}{|c|c|c|c|c|c|c|c|}
\hline \multirow[b]{2}{*}{ Month } & \multicolumn{7}{|c|}{ Temperature $\left({ }^{\circ} \mathrm{C}\right)$ per state, county } \\
\hline & $\begin{array}{c}\text { Alabama, } \\
\text { Montgomery }\end{array}$ & $\begin{array}{c}\text { Florida, } \\
\text { Duval }\end{array}$ & $\begin{array}{c}\text { Mississippi, } \\
\text { Hinds }\end{array}$ & $\begin{array}{l}\text { Georgia, } \\
\text { Bibb }\end{array}$ & $\begin{array}{l}\text { Illinois, } \\
\text { Peoria }\end{array}$ & $\begin{array}{l}\text { Iowa, } \\
\text { Polk }\end{array}$ & $\begin{array}{l}\text { Nebraska, } \\
\text { Lancaster }\end{array}$ \\
\hline \multicolumn{8}{|l|}{ High, month ${ }^{b}$} \\
\hline April & 30.4 & 31.0 & 30.1 & 31.3 & 30.0 & 29.9 & 31.7 \\
\hline May & 33.6 & 34.4 & 32.8 & 33.9 & 30.7 & 31.3 & 33.2 \\
\hline June & 35.1 & 35.1 & 34.6 & 36.1 & 33.8 & 34.0 & 35.1 \\
\hline July & 35.8 & 35.7 & 36.0 & 37.1 & 36.0 & 35.6 & 39.6 \\
\hline August & 36.4 & 34.9 & 35.7 & 36.8 & 34.6 & 35.1 & 38.3 \\
\hline September & 35.3 & 33.8 & 34.7 & 35.0 & 31.7 & 32.6 & 35.4 \\
\hline October & 32.1 & 31.4 & 31.7 & 31.9 & 29.4 & 28.3 & 31.8 \\
\hline November & 29.9 & 30.0 & 29.6 & 29.0 & 21.3 & 22.6 & 24.4 \\
\hline \multicolumn{8}{|c|}{ Daily average $^{c}$} \\
\hline April & 25.4 & 25.9 & 24.8 & 25.4 & 18.2 & 17.8 & 19.0 \\
\hline May & 29.1 & 29.8 & 28.4 & 29.5 & 22.3 & 22.0 & 23.5 \\
\hline June & 31.5 & 31.4 & 31.1 & 32.0 & 27.9 & 27.7 & 29.0 \\
\hline July & 33.1 & 32.6 & 32.9 & 33.8 & 30.1 & 29.7 & 32.4 \\
\hline August & 32.8 & 32.0 & 32.8 & 33.0 & 28.7 & 28.6 & 30.8 \\
\hline September & 31.4 & 30.4 & 30.8 & 30.8 & 26.4 & 26.1 & 27.5 \\
\hline October & 26.2 & 27.3 & 25.7 & 25.8 & 17.7 & 17.2 & 18.6 \\
\hline November & 21.2 & 23.7 & 20.3 & 21.2 & 10.5 & 9.2 & 10.8 \\
\hline
\end{tabular}

a Data for each month were obtained from the National Climatic Data Center and averaged over 4 years, 2002 to 2005.

${ }^{\mathrm{b}}$ High temperature for the month.

${ }^{c}$ Average daily temperature high. Each temperature is the mean temperature based on the number of days in the month, and then averaged.

TABLE 4. Percentage of days for each month (April to November), in which the daily high was $>33^{\circ} \mathrm{C}$ or low was $<4^{\circ} \mathrm{C}$ at each of seven weather stations ${ }^{\mathrm{a}}$

\begin{tabular}{|c|c|c|c|c|c|c|c|}
\hline \multirow[b]{2}{*}{ Temperature, month } & \multicolumn{7}{|c|}{ Days $(\%)$ per state, county } \\
\hline & $\begin{array}{c}\text { Alabama, } \\
\text { Montgomery }\end{array}$ & $\begin{array}{l}\text { Florida, } \\
\text { Duval }\end{array}$ & $\begin{array}{l}\text { Mississippi, } \\
\text { Hinds }\end{array}$ & $\begin{array}{l}\text { Georgia, } \\
\text { Bibb }\end{array}$ & $\begin{array}{l}\text { Illinois, } \\
\text { Peoria }\end{array}$ & $\begin{array}{l}\text { Iowa, } \\
\text { Polk }\end{array}$ & $\begin{array}{l}\text { Nebraska } \\
\text { Lancaster }\end{array}$ \\
\hline \multicolumn{8}{|l|}{ Above $33^{\circ} \mathrm{C}$} \\
\hline April & 0.0 & 3.3 & 3.3 & 3.3 & 0.0 & 0.0 & 3.3 \\
\hline May & 12.9 & 22.6 & 12.9 & 19.4 & 0.0 & 0.0 & 3.2 \\
\hline June & 33.3 & 26.7 & 30.0 & 50.0 & 16.7 & 10.0 & 26.7 \\
\hline July & 67.7 & 54.8 & 61.3 & 77.4 & 29.0 & 22.6 & 51.6 \\
\hline August & 61.3 & 38.7 & 54.8 & 61.3 & 16.1 & 19.4 & 32.3 \\
\hline September & 40.0 & 13.3 & 13.3 & 26.7 & 6.7 & 10.0 & 20.0 \\
\hline October & 3.2 & 0.0 & 0.0 & 3.2 & 0.0 & 0.0 & 3.2 \\
\hline November & 0.0 & 0.0 & 0.0 & 0.0 & 0.0 & 0.0 & 0.0 \\
\hline \multicolumn{8}{|l|}{ Below $4^{\circ} \mathrm{C}$} \\
\hline April & 3.3 & 0.0 & 6.7 & 6.7 & 36.7 & 33.3 & 40.0 \\
\hline May & 0.0 & 0.0 & 0.0 & 0.0 & 9.7 & 9.7 & 16.1 \\
\hline June & 0.0 & 0.0 & 0.0 & 0.0 & 0.0 & 0.0 & 0.0 \\
\hline July & 0.0 & 0.0 & 0.0 & 0.0 & 0.0 & 0.0 & 0.0 \\
\hline August & 0.0 & 0.0 & 0.0 & 0.0 & 0.0 & 0.0 & 0.0 \\
\hline September & 0.0 & 0.0 & 0.0 & 0.0 & 0.0 & 3.3 & 6.7 \\
\hline October & 3.2 & 0.0 & 6.5 & 6.5 & 25.8 & 38.7 & 48.4 \\
\hline November & 26.7 & 10.0 & 26.7 & 33.3 & 73.3 & 80.0 & 86.7 \\
\hline
\end{tabular}

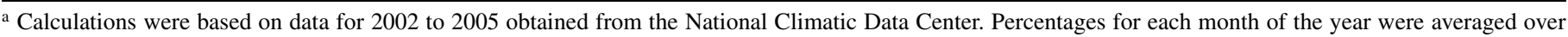
the 4 years. 
lesions formed. Lesions were rare when the temperature peaked at $37^{\circ} \mathrm{C}$ and were not produced at $41^{\circ} \mathrm{C}$ (Fig. 1).

Numbers of uredinia per lesion and uredinium diameters. Uredinia per lesion was greatest when the day temperature peaked at $25^{\circ} \mathrm{C}$ (11.1 uredinia/lesion) and $29^{\circ} \mathrm{C}$ (11.3 uredinia/lesion) (Fig. 2). Average uredinium diameters were significantly greater with the $17^{\circ} \mathrm{C}$ temperature peak $(156 \mu \mathrm{m})$ than at any other temperature pattern, and average uredinium diameters gradually decreased as the peak temperature rose $\left(120 \mu \mathrm{m}\right.$ at $\left.37^{\circ} \mathrm{C}\right)$ (Fig. 3).

The greatest SPAL was when the temperature peaked at 25 or $29^{\circ} \mathrm{C}$ (Fig. 4). Average SPAL at $25^{\circ} \mathrm{C}$ was significantly greater than for all other temperature patterns, except when the temperature peaked at $29^{\circ} \mathrm{C}$ (Fig. 4).

Numbers of urediniospores. The greatest urediniospore production peaked 18 to 24 days after inoculation for each temperature pattern. The greatest cumulative number of urediniospores (per square centimeter of leaf area), collected up to 33 days after

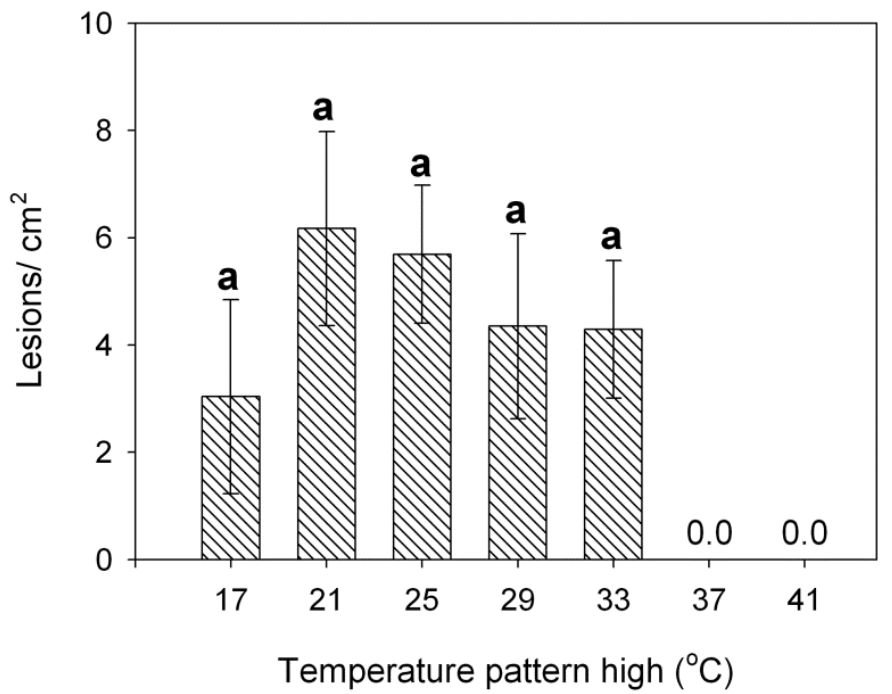

Fig. 1. Mean numbers of lesions produced per square centimeter of leaf area on plants incubated under specific diurnal temperature patterns with temperature peaks of 17 to $41^{\circ} \mathrm{C}$. The difference between the diurnal temperature highs and lows was $13^{\circ} \mathrm{C}$ for each temperature pattern. Standard errors of the means are indicated.

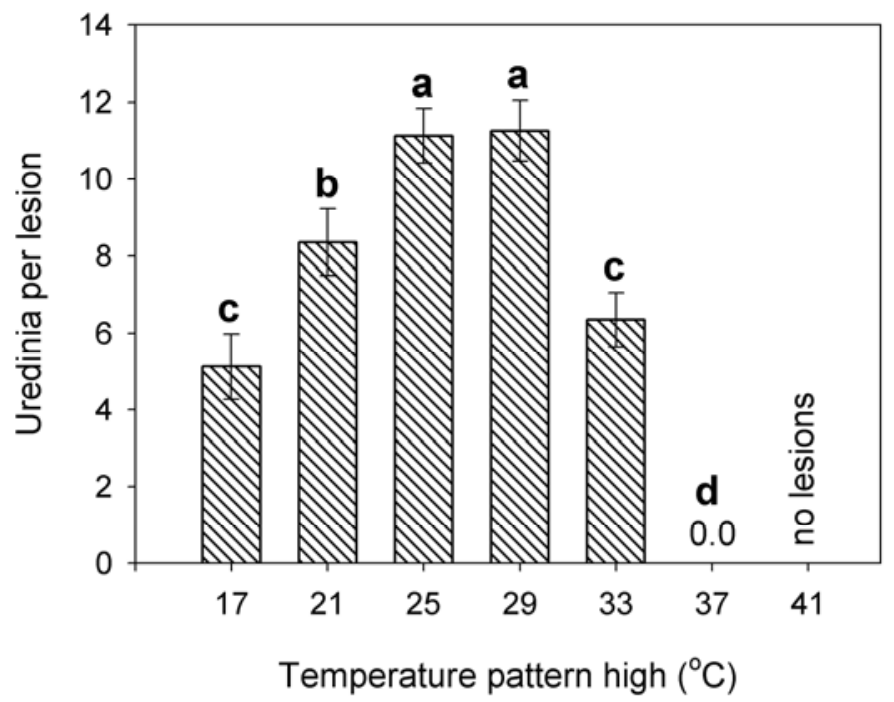

Fig. 2. Mean numbers of uredinia per lesion on inoculated soybean plants incubated under specific diurnal temperature patterns with diurnal temperature highs of 17 to $41^{\circ} \mathrm{C}$. The difference between the diurnal temperature highs and lows was $13^{\circ} \mathrm{C}$ for each specific temperature pattern. Standard errors of the means are indicated. inoculation occurred when the day temperature peaked at $25^{\circ} \mathrm{C}$ and night temperature dipped to $12^{\circ} \mathrm{C}$, significantly different from all other temperature patterns, except $21^{\circ} \mathrm{C}$ day and $8^{\circ} \mathrm{C}$ night (Fig. 5). When the temperature peaked at 29,33 , and $37^{\circ} \mathrm{C}$, cumulative urediniospore production per square centimeter of leaf area was 36,19 , and $0 \%$, respectively, of that produced under the optimum temperature pattern (Fig. 5). The greatest number of cumulative urediniospores per uredinium occurred with a peak temperature of $21^{\circ} \mathrm{C}$ (444 urediniospores/uredinium) and $25^{\circ} \mathrm{C}$ (493 urediniospores/uredinium) (Fig. 6).

Mean daily maximum and minimum temperatures for representative southeastern and Midwestern states. The average monthly temperature high and average daily maximum temperature for each month, April to November, of 2002 to 2005 are presented in Table 3. As expected, July and August were the hottest months regardless of location. The highest single-day temperature in Alabama in July and August, averaged over 4 years,

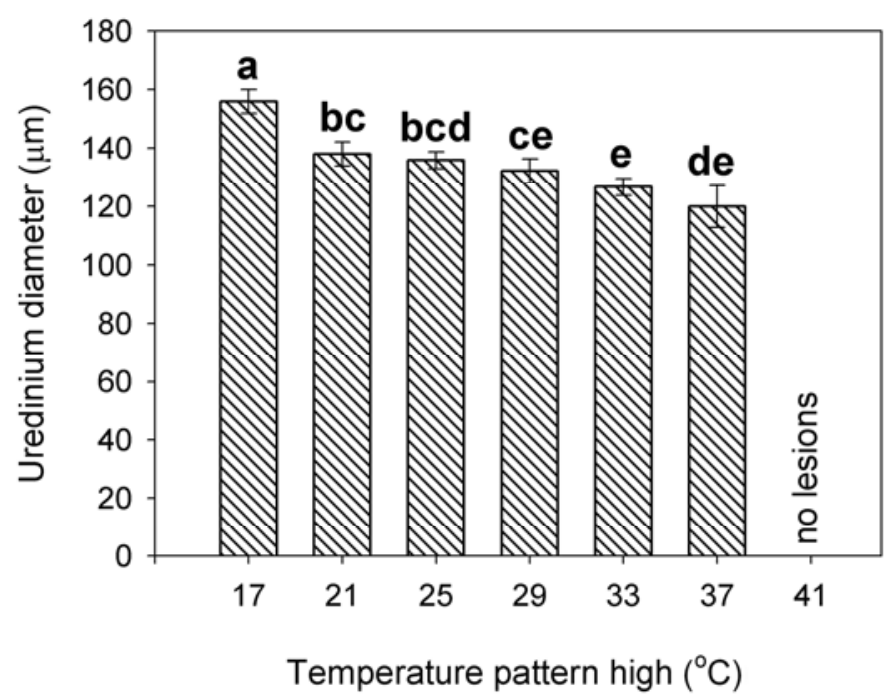

Fig. 3. Mean uredinium diameters on inoculated soybean plants incubated under specific diurnal temperatures with diurnal temperature highs of 17 to $41^{\circ} \mathrm{C}$. The difference in diurnal temperature highs and lows was $13^{\circ} \mathrm{C}$ for each specific temperature pattern. Standard errors of the means are indicated.

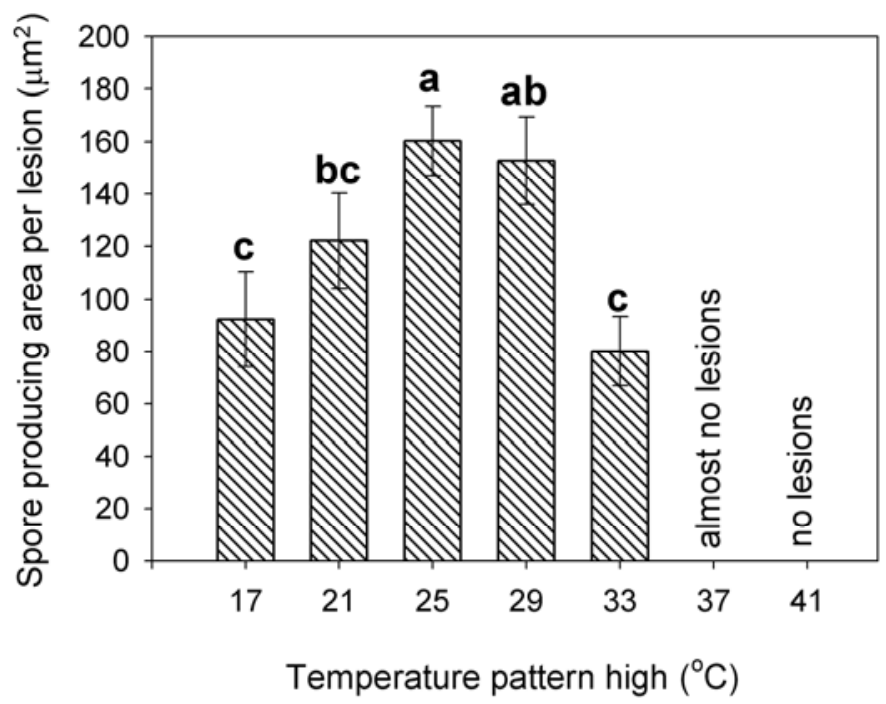

Fig. 4. Mean spore-producing area per lesion SPAL for inoculated soybean plants incubated under specific diurnal temperature patterns with diurnal temperature highs of 17 to $41^{\circ} \mathrm{C}$. The difference between the diurnal temperature highs and lows was $13^{\circ} \mathrm{C}$ for each specific temperature pattern. Standard errors of the means are indicated. 
was 35.8 and $36.4^{\circ} \mathrm{C}$, respectively (Table 3 ). The average daily maximum for Alabama in July and August was 33.1 and $32.8^{\circ} \mathrm{C}$, respectively. In Georgia, the highest single-day temperature during July and August, averaged over 4 years, was 37.1 and $36.8^{\circ} \mathrm{C}$, respectively, and average daily maximum for July and August was 33.8 and $33.0^{\circ} \mathrm{C}$, respectively. It was apparent that $33^{\circ} \mathrm{C}$ was surpassed repeatedly in the southeastern states. In contrast, average highs for Illinois and Iowa for the same months were several degrees lower (Table 3).

The percentages of days in which the temperature exceeded $33^{\circ} \mathrm{C}$ at the respective weather stations are presented in Table 4. For Georgia, the temperature exceeded $33^{\circ} \mathrm{C}$ on $77 \%$ of days during July. This was followed by $68 \%$ for Alabama, $61 \%$ for Mississippi, 55\% for Florida, and 52\% for Nebraska. For August, $61 \%$ of days in Georgia and Alabama exceeded $33^{\circ} \mathrm{C}$, followed by $55 \%$ for Mississippi and $39 \%$ for Florida. In contrast, for Iowa, only 23 and $19 \%$ of days during July and August, respectively, exceeded $33^{\circ} \mathrm{C}$; for Illinois, 29 and $16 \%$ of days during July and August, respectively, exceeded $33^{\circ} \mathrm{C}$. In general, during the summer months of June to August, Georgia had the greatest percentage of days deemed to be too hot for good urediniospore production, followed by Alabama, Mississippi, Florida, Nebraska, Illinois, and Iowa, in that order.

Although not an objective of this study, the frequencies for days in which the temperature low was $<4^{\circ} \mathrm{C}$, deemed to be too low for good urediniospore production, was greatest for Nebraska, Iowa, and Illinois, in that order.

\section{DISCUSSION}

The purpose of our study was to determine the effects of diurnal temperature highs on soybean rust development. Although temperature averages are helpful in predicting disease epidemics (20), they do not reflect the effects caused by temperature extremes. In this article, we use the phrase "temperature extremes" to denote temperatures $>33^{\circ} \mathrm{C}$, even though these temperatures are not particularly high and are common during summer months. Temperature extremes, even for brief periods (e.g., $1 \mathrm{~h}$ ), affect disease to a much greater extent than do temperature means (24). For example, 2 days can have identical mean temperatures, yet have large differences in temperature fluctuations. During a few days when the temperature reaches an extreme level, the negative effect on a pathogen's reproductive

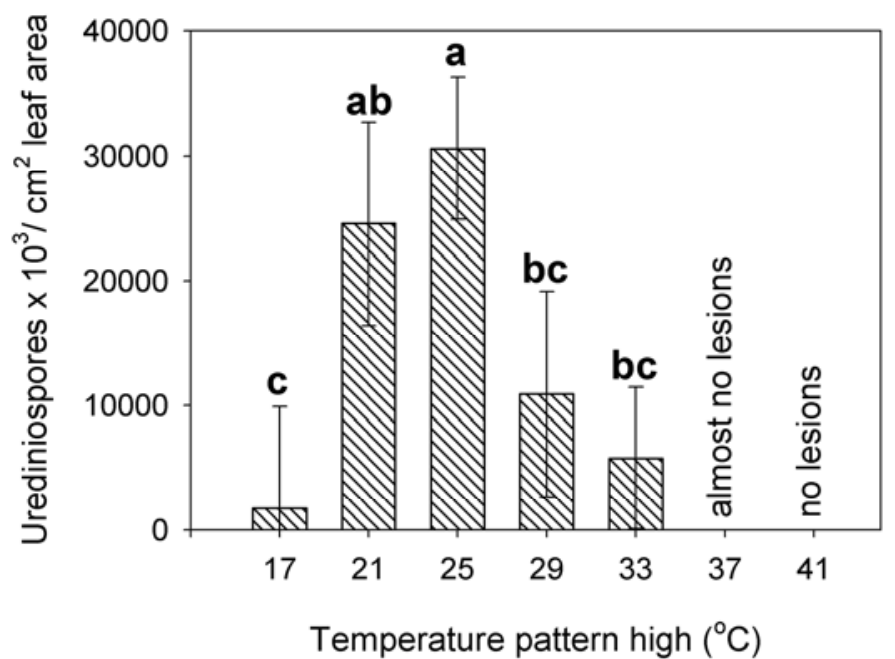

Fig. 5. Mean numbers of urediniospores produced per square centimeter of leaf area on inoculated soybean plants incubated under specific diurnal temperature patterns with diurnal temperature highs of 17 to $41^{\circ} \mathrm{C}$. The difference between the diurnal temperature highs and lows was $13^{\circ} \mathrm{C}$ for each specific temperature pattern. Standard errors of the means are indicated. rate can offset the positive effects caused by more moderate temperatures (24). For this reason, we concentrated our efforts on determination of effects caused by temperature extremes.

To conduct the study, it was necessary to isolate temperature differences from other factors which also affect disease. RH was monitored in each growth chamber. The maximum $\mathrm{RH}$ occurred at night and peaked at 82 to $96 \%$, depending on the temperature conditions. The minimum $\mathrm{RH}$ for each temperature pattern occurred in the day and peaked at 24 to $76 \%$, depending on temperature conditions. The lowest $\mathrm{RH}$ was at $41^{\circ} \mathrm{C}$ and the highest at $4^{\circ} \mathrm{C}$. In a separate study, in which RH was held at 20 or $92 \%$ for the duration of the postinoculation period, $\mathrm{RH}$ had no significant effect on numbers of lesions or urediniospores. This indicated that $\mathrm{RH}$ was not responsible for differences in numbers of lesions or urediniospores produced in this study.

Because leaf and air temperatures in the respective growth chambers were nearly identical, we can assume that the temperatures experienced by the pathogen within infected leaves were essentially identical to the air temperatures reported in this article. In the field, leaf and air temperatures can be different by several degrees, depending on several factors, including wind speed, $\mathrm{RH}$, radiation, ambient air temperature, and transpiration rate (9). Relationships between leaf and air temperatures can be complex, involving energy balances between the leaf and air, but we note that, at the temperatures of greatest interest to us (i.e., 30 to $40^{\circ} \mathrm{C}$ ), they are rather simple. Gates (9), when comparing several plant species in a growth chamber (with 1,700 foot-candles and $65 \% \mathrm{RH}$ ), reported that, at air temperatures between 30 and $40^{\circ} \mathrm{C}$, air and leaf temperatures were nearly identical. Drake et al. (7) showed that, at $35^{\circ} \mathrm{C}$, Xanthium leaves were at the same temperature as the ambient air temperature regardless of wind speed.

The most informative temperature highs in our study were those in which the diurnal temperature maxima were the greatest (i.e., 33, 37, and $41^{\circ} \mathrm{C}$ ) because, from these, it was possible to estimate the diurnal temperature high at which any temperature increase would significantly reduce urediniospore production and disease. When the daily temperature peaked at $33^{\circ} \mathrm{C}$, urediniospore production was only $19 \%$ of that when the daily high was at its optimum $\left(25^{\circ} \mathrm{C}\right)$. When the temperature peaked at $37^{\circ} \mathrm{C}$ or above, urediniospore production was near zero. The number of lesions per square centimeter of leaf area also was near zero when the temperature high reached $37^{\circ} \mathrm{C}$, corroborating results from urediniospore counts. The frequency in which the daily tempera-

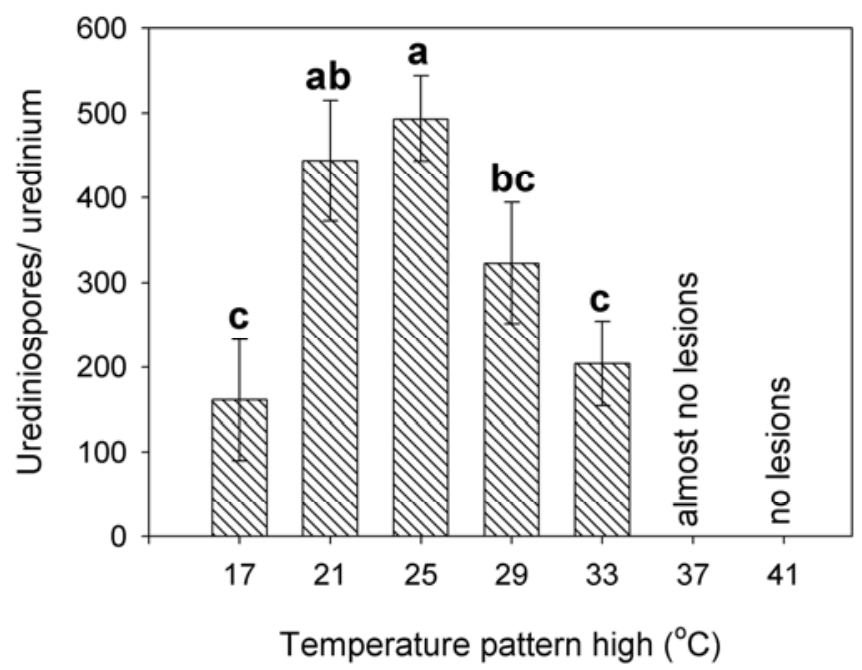

Fig. 6. Mean numbers of urediniospores produced per uredinium on inoculated soybean plants incubated under specific diurnal temperature patterns with temperature highs of 17 to $41^{\circ} \mathrm{C}$. The difference between diurnal temperature highs and lows for each temperature pattern was $13^{\circ} \mathrm{C}$. Standard errors of the means are indicated. 
ture high was $33^{\circ} \mathrm{C}$ or higher was 39 to $77 \%$ during July and August throughout the southeastern United States, causing us to conclude that daily temperature highs likely contributed to restriction of soybean rust development.

The average SPAL is a measure of the capacity for a rust pathogen to produce inoculum and is calculated from both the average number of uredinia per lesion and average uredinium diameter. Thus, it is more comprehensive than numbers of uredinia per lesion. We have previously used SPAL and determined it to be useful for making comparisons, particularly in situations when lesion densities were highly variable $(2,3)$. In this study, maximum SPAL and maximum number of uredinia per lesion occurred at 25 to $29^{\circ} \mathrm{C}$; at $31^{\circ} \mathrm{C}$ and above, they both were near zero.

Our study focused on temperature highs. Using a similar approach for temperature lows, data suggested that cool nights during October and November would decrease soybean rust development in Midwestern and northern states (e.g., Illinois, Iowa, and Nebraska) if the pathogen were present (Table 3). When the air temperature of the growth chamber dipped to $4^{\circ} \mathrm{C}$, there was a marked decrease in numbers of lesions and urediniospores. Although of interest, the effects of temperature lows on soybean rust are not particularly important in the United States because, by the time of year temperature lows of $4{ }^{\circ} \mathrm{C}$ and below are reached, grain development is nearly complete. Initiation of infection would have little effect on crop yield or quality. However, low temperatures probably do affect pathogen survival through winter months.

We determined for the first time that $P$. pachyrhizi is sensitive to "high" $\left(33^{\circ} \mathrm{C}\right.$ and above) temperatures, even for brief periods. The frequencies at which the temperature is exceeded strongly suggest that temperature may be a factor in restricting soybean rust development during summer months in the southeastern United States. This conclusion is supported by observations summarized by Bromfield (5) that, in Asia, where multiple soybean cropping per year is practiced, soybean rust was more severe during the cooler seasons, accompanied by rains.

It appears that the environment, specifically temperature highs, contributed to the constraint of soybean rust development in the southeastern United States. The lack or delay of the disease here not only affects local production but also has major implications for soybean production in Midwestern and northern states, where the bulk of soybeans are grown.

We examined effects of diurnal temperature patterns in which each temperature high was repeated every $24 \mathrm{~h}$ for the duration of the experiment. Although not in the scope of the present study, future research should include determination of number of days specific temperatures must be met or exceeded for disease to be affected and, once temperatures became less extreme, time required for disease development to resume. We can reasonably assume that the fewer the days that extreme temperatures are met, the less effect temperature would have on urediniospore production and numbers of lesions. This is an important aspect of soybean rust that should be addressed but will require considerable research effort.

In spite of strong evidence that high temperatures limit soybean rust development, other factors also play roles in limiting the disease. For example, a lack of sufficient moisture on the surface of plants would restrict urediniospore germination and infection. Air currents and winds are required for urediniospore transport. Without this transport into an area, disease will not occur if not already present. Susceptible soybean or alternative host plants are required for inoculum build-up as the disease progressively moves from south to north during the cropping season. During longdistance urediniospore transport, spores are exposed to sunlight, known to be detrimental to their viability (11). Isard et al. (11) have suggested that the risk of soybean rust establishment in the continental interior from trace or low numbers of spores may be minimal because most urediniospores do not remain viable. All of these factors may explain why soybean rust often fails to develop or develops late in the season. Knowledge of how these factors individually and together affect soybean rust development will lead to better and more cost-effective control measures and perhaps prevent unnecessary use of chemicals.

\section{ACKNOWLEDGMENTS}

The United States Department of Agriculture (USDA) prohibits discrimination in all its programs and activities on the basis of race, color, national origin, age, disability, and, where applicable, sex, marital status, familial status, parental status, religion, sexual orientation, genetic information, political beliefs, reprisal, or because all or a part of an individual's income is derived from any public assistance program. (Not all prohibited bases apply to all programs.) Persons with disabilities who require alternative means for communication of program information (Braille, large print, audiotape, and so on) should contact USDA's TARGET Center at 202-720-2600 (voice and TDD). To file a complaint of discrimination, write to USDA, Director, Office of Civil Rights, 1400 Independence Avenue, SW, Washington, DC 20250-9410 or call 800-7953272 (voice) or 202-720-6382 (TDD). USDA is an equal opportunity provider and employer.

\section{LITERATURE CITED}

1. Bonde, M. R., Berner, D. K., Nester, S. E., and Frederick, R. D. 2007. Effects of temperature on urediniospore germination, germ tube growth, and initiation of infection in soybean by Phakopsora isolates. Phytopathology 97:997-1003.

2. Bonde, M. R., Nester, S. E., Austin, C. N., Stone, C. L., Frederick, R. D., Hartman, G. L., and Miles, M. R. 2006. Evaluation of virulence of Phakopsora pachyrhizi and P. meibomiae isolates. Plant Dis. 90:708-716.

3. Bonde, M. R., Nester, S. E., Berner, D. K., Frederick, R. D., Moore, W. F., and Little, S. 2008. Comparative susceptibilities of legume species to infection by Phakopsora pachyrhizi. Plant Dis. 92:30-36.

4. Bonde, M. R., Nester, S. E., Moore, W. F., and Allen, T. W. 2009. Comparative susceptibility of kudzu accessions from the southeastern United States to infection by Phakopsora pachyrhizi. Plant Dis. 93:593598.

5. Bromfield, K. R. 1984. Soybean Rust. Monogr. No. 11. American Phytopathological Society, St. Paul, MN.

6. Cherry, E., and Peet, C. E. 1966. An efficient device for the rapid collection of fungal spores from infected plants. Phytopathology 56:11021103.

7. Drake, B. G., Raschke, K., and Salisbury, F. B. 1970. Temperatures and transpiration resistances of Xanthium leaves as affected by air temperature, humidity, and wind speed. Plant Physiol. 46:324-330.

8. Eversmeyer, M. G., and Burleigh, J. R. 1970. A method of predicting epidemic development of wheat leaf rust. Phytopathology 60:805-811.

9. Gates, D. M. 1968. Transpiration and leaf temperature. Annu. Rev. Plant Physiol. 19:211-238.

10. Hennings, P. 1903. Some new Japanese Uredinales. IV. Hedwigia (Suppl.):107-108. (In German)

11. Isard, S. A., Barnes, C. W., Hambleton, S., Ariatti, A., Russo, J. M., Tenuta, A., Gay, D. A., and Szabo, L. J. 2011. Predicting soybean rust incursions into the North American continental interior using crop monitoring, spore trapping, and aerobiological modeling. Plant Dis. 95:1346-1357.

12. Kenward, M. G., and Roger, J. H. 1997. Small sample inference for fixed effects from restricted maximum likelihood. Biometrics 53:983-997.

13. Lang, C. T., Kingsolver, C. H., Mitchell, J. E., and Cherry, E. 1958. Determination of the effects of different temperatures on uredial infection with Puccinia graminis var. tritici. Phytopathology 48:658-660.

14. Levy, C. 2005. Epidemiology and chemical control of soybean rust in southern Africa. Plant Dis. 89:669-674.

15. Li, X., Mo, J., Guo, T., and Yang, X. 2010. Effects of light on urediniospore germination, appressorium formation and infection efficiency of Phakopsora pachyrhizi, causal agent of soybean rust. Can. J. Plant Pathol. 32:153-161.

16. Melching, J. S., Dowler, W. M., Koogle, D. L., and Royer, M. H. 1989. Effects of duration, frequency, and temperature of leaf wetness periods on soybean rust. Plant Dis. 73:117-122.

17. Melhus, I. E., and Durrell, L. W. 1919. Studies on the crown rust of oats. Iowa Agric. Exp. Stn. Res. Bull. 49.

18. Morel, W., and Yorinori, J. T. 2002. Situacion de la roja de la soja en el Paraguay. Bol de Diulgacion No. 44. Ministerio de Agricultura y 
Granaderia, Centro Regional de Investigacion Agricola, Capitan Miranda, Paraguay.

19. Narvaez, D. F., Jurick, W. M., II, Marois, J. J., and Wright, D. L. 2010. Effects of surface wetness periods on development of soybean rust under field conditions. Plant Dis. 94:258-264.

20. Pivonia, S., and Yang, X. B. 2005. Assessment of epidemic potential of soybean rust in the United States. Plant Dis. 89:678-682.

21. Politowski, K., and Browning, J. A. 1975. Effect of temperature, light, and dew duration on relative numbers of infection structures of Puccinia coronata avenae. Phytopathology 65:1400-1404.

22. Rossi, R. L. 2003. First report of Phakopsora pachyrhizi, the causal organism of soybean rust in the Province of Misiones, Argentina. Plant Dis. 87:102.

23. Schneider, R. W., Hollier, C. A., Whitman, H. K., Palm, M. E., McKemy, J. M., Hernandez, J. R., Levy, L., and DeVries-Patterson, R. 2005. First report of soybean rust caused by Phakopsora pachyrhizi in the continental United States. Plant Dis. 89:774.

24. Van den Berg, F., and van den Bosch, F. 2007. The elasticity of the epidemic growth rate to observed weather patterns with an application to yellow rust. Phytopathology 97:1512-1518.

25. Wallin, J. R. 1963. Dew, its significance and measurements in phytopathology. Phytopathology 53:1210-1216. 